\title{
Türkiye’de Kamusal Müzakere Deneyimleri: Batman Üniversitesi Çalıştay Örneği
}

\section{Publıc Negotiation Experıence In Turkey: Batman Untversity Workshop Example}

\author{
Gülsüm Hekimoğlu ${ }^{\text {a,* }}$ \\ a Öğr. Görevlisi, Dr. Batman Üniversitesi, Sağlık Hizmetleri MYO, 72060, Batman/Türkiye. \\ ORCID: 0000-0003-1372-1088
}

\section{MAKALE BILGGISI}

\section{Makale Geçmişi:}

Başvuru tarihi: 02 Şubat 2019

Düzeltme tarihi: 10 Mayıs 2019

Kabul tarihi: 15 Mayıs 2019

\section{Anahtar Kelimeler:}

Demokratik Müzakere

Kamusal Alan

Kat1lım

Demokrasi

Çalıştay

\section{A R T I C LE INFO}

Article history:

Received 02 February 2019

Received in revised form 10 May 2019

Accepted 15 May 2019

\section{Keywords:}

Democratic Negotiation

Public Space

Participation

Democracy

Workshop
ÖZ

Değişen toplumla birlikte sosyal problemlerde değişmektedir. Günümüz toplumları geçmişteki toplumlara oranla daha talihli görünebilir. Ancak her toplum kendine özgü problemlere sahiptir. İletişimsel demokrasi ve eşit katılım, günümüz toplumlarının en hassas problemlerindendir. Temsili demokrasi, bireyleri temel demokratik süreçlerden dışlamakta ve yurttaşları katılımcı eylemlerden uzaklaştırmaktadır. Bu çalışma temsili demokrasinin sonuçlarından kaynaklanan eşitsizliklerin üstesinden gelebilecek alternatif seçenekleri değerlendirmeyi amaçlamaktadır. $\mathrm{Bu}$ amaç doğrultusunda, bu çalışmada, üniversitedeki bir bilimsel toplantı kamusal müzakere deneyimi açısından değerlendirilmiştir. Çalışma, nitel araştırma yöntemi ile hazırlanmış bir söylem analizini içermektedir. Böylesi bir söylemsel etkileşim mekânı, bireylere fikirlerini ifade edebilme ve rakip fikirlerle karşılaşma imkanı sunmasına ve dahası ortak yaşamlarıyla ilgili birlikte eyleme potansiyeli taşımasına rağmen, temsili demokrasinin bunalımını aşamamış ve güç asimetrilerinden kaynaklanan eşitsizliklerin üstesinden gelememiştir.

\section{A B S T R A C T}

Changes in social problems with changing society. Today's societies may seem more fortunate than past societies. However, every society has its own problems. Communicative democracy and equal participation are the most sensitive problems of today's societies. Representative democracy, excludes individuals from basic democratic processes and removes citizens from participatory actions. This study aims to evaluate the alternative options that can overcome the inequalities arising from the results of representative democracy. For this purpose, in the study, a scientific meeting in the university was evaluated in terms of the public negotiation experience. The study includes a discourse analysis prepared by qualitative research method. Such a space for discursive interaction has not been able to overcome the crisis of representative democracy and overcome the inequalities arising from force asymmetries, despite the fact that it offers individuals the opportunity to express their ideas and to meet rival ideas and, moreover, has the potential to act together on their shared lives.

\section{Giriş}

Demokratik meşruiyetin, demokrasinin kamusal alana yaygınlaştırılmasıyla sağlanabileceği düşüncesi bu çalışmanın mahrecidir. $\mathrm{Bu}$ yüzden bu çalışma temsili demokrasi sistemindeki -katılım ve müzakere gibi- kimi krizlerin üstesinden gelebilecek opsiyonları değerlendirmeyi hedeflemektedir. Çalışmada, toplumsal hareketler, kolektif eylem ve aktif yurttaş katılımı önemsenmektedir. Dolayısıyla yurttaşlar arasındaki etkileşim ve diyaloğa dayalı kamusal konuşma eylemlerine odaklanılmaktadır. Bu çalışmada demokrasi sorunu, normatif değerlendirmelerin dışında, yurttaşların müşterek yaşamlarıyla ilgili sorunlar hakkında toplanması, eylemesi ve müzakere etmesi yoluyla aşılabileceği savı etrafında değerlendirilecektir.

Bugün Türkiye'de demokrasiye yönelik egemen bakışın mayasını oluşturan görüş, temsili demokrasidir. Oysa temsili

*Sorumlu yazar/Corresponding author

e-posta: glsmkymk@hotmail.com 
demokrasi yurttaşların kamusal konuları ve konular hakkındaki kararları saptamak yerine bunlar hakkında karar verebilecek temsilcileri saptamakla yetinmeleri nedeniyle sorunludur. Fakat bu açmaz yeterince sorun edilmemekte ve değişmesi gereken yanları için yeterince düşünülmemektedir.

$\mathrm{Bu}$ durum Türkiye'nin içinden süzülüp geldiği tarihsel sürecin karakteristiği ile yakıdan ilgili gibidir. Öyle ki, hanedanlığın dışındaki 'kimselerle' ilişki içinde olmaya sıcak bakmamış olan Osmanlı, kendine karşı tehdit oluşturabilecek her türlü çoğunlukçu etkinliği denetim altında tutmuştur. Gerçi 18. yy. da İmparatorluk "kendi varlığını Batı'da yaşanan milliyetçilik gibi gelişmelere karşı koruyabilmek ve Batı'ya karşı yeniden üstünlüğünü elde edebilmek için bir proje olarak Osmanlıcılık kimliği adı altında" bir çözüm formüle etmeye çalışmıştır" (Koç, 2018: 277). "Osmanlıcılık ile birlikte sultan-tebaa diyalektiği yerini vatan-yurttaş diyalektiğine bırakmıştır. Önceki egemen düşüncede sultan mutlak güçken, bütün topraklar sultanın malıyken, sultanın yönetmiş olduğu topraklardaki yönetilenler sultanın kuluyken; Osmanlıcılık cereyanı ile birlikte 'Padişahın tebaaları' düşüncesi yerini 'Osmanlı'nın Yurttaşları'na bırakmıştır (Koç, 2018: 268). Ancak kamusal müzakere açısından değerlendirildiğinde bu 'Modernist' çaba cazip sonuçlar doğuramamıştır. Bireylerin kendi içinde örgütlenebileceği, kanaatlerini özgürce ifade edebileceği ve eyleyebileceği alanlar akim kalmıştır. Kendi kaderini tayin edebilen, yönetimini seçebilen bir halk yerine, ölçülü haklarla ve kimi sınırlılıklarla kuşatılmış bir tebaa söz konusudur.

Önceden cemaatler vasıtasıyla ve gevşekçe bir bağla devlete bağlı olan klasik Osmanlı tebaası İmparatorluğun yıkıntıları arasından kurulacak ulus-devletin inşası sürecinde değişmiştir. Zaten "Tanzimat'tan beri (özellikle aydın kesim tarafından) ince ince işlenegelen ulusçuluk/Türkçülük fikri ayağa kaldırılmaya çalışılmıştır" (Palabıyık ve Koç, 2015: 428). Cumhuriyet dönemiyle birlikte "daha önce görece başıboş olan tebaa, devlet ve toplum arasındaki ilişkilerin hukukla ve kurallarla düzenlendiği bir ilişkinin 'vatandaşı' haline gelmiștir" (Hülür ve Akça, 2007: 313). Cumhuriyet, emperyalist yayılmacılığın etkisinde kalmamak için ve hatta emperyalizme karşı duruş sergileme noktasında örnek olacağı için kuruluş felsefesini bağımsızlık olarak kodlamıştır. Sonuçta, tebaayı kendine yetebilen bir halka ve kendi yönetim kaderini saptayabilen aktif aktörlere dönüştürmeyi başarabilmiş olan Cumhuriyet, gerek bağımsızlık gerekse ekonomik kalkınma planlarına sadık şekilde ilerlemeye devam etmiştir. Böylece bağımsızlık odaklı kurucu söylem, halkı siyasi bağlamda etken vatandaş konumuna yükselten kültürün dizginlerini elinde s1k1 sık1 tutmuştur. Türkiye toplumunun kurucu zihniyeti, karşısında hak ve ödevlerle devlete bağlanan bir 'vatandaşlar birliği' tasarlamıştır. Bu vatandaşlar kamusal alana katılırken daha çok ideolojik saik ile hareket eden ve etnik, dinsel, cinsel ya da daha farklı itkilerden hareketle devlete kanal açmaya çalışmayan vatandaşlar birliğidir. Böylece toplumsalın kendini kamuoyunun belirleyicisi olarak örgütleyebildiği vatandaş alanları daha bağdaşı bir kültür tarafından şekillenmiştir.

Demokratikleşme yasal ve kurumsal normatif düzenlemelerle değil, kamusal alanın farklı zeminlerinde deneyimlenmesi gereken bir süreçtir. Dolayısıyla
Türkiye'nin demokrasi geleneğini besleyen bazı damarlar cılız kalmıştır. Türkiye, iletişimsel demokrasi, aktif yurttaşlık, sosyal ve siyasal katılım konularında kimi paradokslara sahip bir ülke olarak temsili demokrasinin krizlerini yaşamaktadır. Demokrasiyi sadece yönetsel bir tavır olarak değerlendiren bu yapı, siyasal eylemden uzaklaşma hali ve siyasetin medyatikleşmesi bu durumu pekiştirmektedir. Bu yüzden Türkiye demokrasisinin özgün koşulları içinde vatandaş etkinliklerini ve yurttaş katılımlarını değerlendirmeyi amaçlayan bu çalışma, müzakereci süreçlerin işleyiş mekanizmalarını açığa çıkarmayı hedeflemekte ve müzakere deneyimlerinin demokratik potansiyellerini irdelemeye çalışmaktadır. Böylece demokratik müzakerenin kamusal yaşamın farklı deneyimlerini kapsayan yurttaş katılımı açısından taşıdığı önem ortaya konmak istenmiştir.

\section{Demokratik Müzakerenin İmkânı İçin Kamusal Alanlar}

\subsection{Neden Demokrasi?}

Eski Yunanca Demokratia kavramından türeyen "demokrasi kavramı, demos ile cratos mefhumlarından gelmektedir. Demos kavramı, deme (mahalle) sözcüğünden türetilmiş olup 'mahallede yaşayan halk' anlamına gelmektedir' (Ertan, 2004:205). Halkın kendini yönetme şekli olarak tanımlanan demokrasi, egemenliğin halka ait olması anlamına gelmektedir (Derdiman, 2006:91). İktidarın halkın elinde olmasına vurgu yapması nedeniyle oldukça dirimsel bir öneme sahiptir.

Tarihsel süreç içinde zenginlerin iradesiyle şekillenen oligarşi, tek bir kişinin iradesine dayanan tiranlık, "soyluların yönetimi olan aristokrasi ve halkın kendini yönettiği sistem olan demokrasi gibi çeşitli yönetim biçimleri ortaya çıkmıştır" (Yatkın, 2006:443). Antik Yunan sitelerinde uygulanan doğrudan demokrasi örnekleri, ilk demokrasi deneyimleri sayılabilir. $\mathrm{Bu}$ deneyimde, halk agoralarda toplanmakta kendileri ile ilgili olan ya da olmayan konulardaki kararlarını yöneticilere doğrudan bildirmektedir. İlk bakışta son derece cazip gelen bu yönetim tarzında söz konusu haklardan ve özgürlüklerden sadece vatandaşlar faydalanabilmekte, köleler, kadınlar ve gençler ise hiçbir şekilde katılımda bulunamamaktadırlar. Bu yüzden eski Yunan kent devletlerindeki demokrasi esasen gerçek bir demokrasi örneği sayılamaz. Bu yanıyla, Antik Yunan Demokrasisi'nde her ne kadar katılım ve karar hakkı gibi olanaklar bulunsa da, uygulanan demokrasi sonuçta mutlak ve bir tek kişinin söz sahibi olması niteliğini taşımaktadır (Giritli ve Sarmaşık, 2001: 49). Kentte yaşayanlara ait bu sınırlı katılımda, gelir düzeyi yüksek ve erkek olan yurttaşlar grubunun katılım ve söz hakkı vardır. Ki, o da sınırlıdır.

Uygulamada yaşanan farklılıklara bağlı olarak modern demokrasinin çeşitli boyutları varlık kazanmıştır. Siber, radikal, delegasyoncu, uzlaşmacı, militan ve plebistçi gibi demokrasinin pek çok türü vardır. Lakin çoğulcu, katılımcı, temsili ve müzakereci modeller bilinen demokrasi modelleri olarak karşımıza çıkmaktadır. "Temsili demokrasi, halkın yönetim hakkını seçtikleri temsilciler eli ile kullandığı yöntemdir; genel uygulama olarak benimsenmiştir. Halk kendisi adına karar verecek kişileri belirli dönemlerle sınırlı olmak üzere seçer ve seçilenler, halk adına halkı yönetirler. Temsili demokrasinin dayandığı ilkeler; özgürlük, eşitlik, 
çoğunluğun yönetme hakkı ve seçim ilkeleridir. Çoğulcu demokraside, vatandaş haklarını savunmak için aktif vatandaş halini alır ve örgütlenir. Katılımcı demokraside ise, ister azınlık, ister çoğunluk olsun, her çeşit grup fikirlerini postmodernist bir çerçevede yansıtabilir. İdeal demokrasiye yakın olan katılımcı demokrasidir" (Kaypak, 2012: 174). Müzakereci demokraside ise "devlette kurum ve kuralların oluşturulması, her türlü sorunların çözümünde karşılıklı görüşmeye, danışmaya ağırlık veren bir yaklaşım esas alınmaktadır" (Derdiman, 2006: 117).

"Liberal demokrasi çoğu zaman demokrasinin kısaltması olarak da kullanılmaktadır" (Akt. Akıncı, 2011: 14). Liberal demokrasilerde politik örüntü, seçimlerle biçimlenir. "Bu demokrasi patiğinde belirli aralıklarla seçim yapılır. Seçimlerde gizli oy açık sayım ilkesi uygulanır ve siyasal iktidar seçimlerle el değiştirir (Akıncı, 2011: 15). Bu avantajlarına rağmen liberal demokrasi modelinin aşamadığı sorunları çözebilmek için kimi seçenekler bulunmaktadır. Müzakereci demokrasi, liberal demokrasinin günümüz dünyasında toplumların karşı karşıya kaldığı sorunları çözemediği ve hatta meşruiyet krizi yaratarak yeni bulanımlar oluşturduğu fikri çerçevesinde ortaya atılan alternatif bir seçenektir.

Tarihsel süreç içindeki deneyimlemeler demokrasinin daha derin ve geniş tanımlamalarla anlatılmasına neden olmuştur. Demokrasi, toplumdaki farklı kesimleri, çeşitlilikleri ve yapısal dişlamalara maruz kalabilenleri siyasi karara katmaya olanak sağlayan bir yönetim şeçeneği olarak karşımıza çıkmaktadır. Bu noktada doğabilecek sorunların çözülebilmesine yasal temel hazırlayabilen bir sistem olarak belirmektedir (Görmez,1997:12). Demokratikleşme her şeyden evvel Keyman'ın ifadeleriyle; "Modern bürokratik devletin yasal-rasyonel hareket tarzını iletişimsel ussallık temelinde katılımcı demokratik yönetime dönüştürme sürecini niteler" (Keyman, 2007: 68). Demokrasi kavram1, farklı kanaat, tarz ve düşüncelere anlayışlı olmayı ifade etmektedir. Demokrasiye inanmayı ifade etmektedir.

\subsection{Temsili Demokrasinin Krizlerini Aşmak İçin Kamusal Alanların Önemi}

Modern demokrasinin var olan sorunlar karşısında etkisiz ve verimsiz kaldığı gözleminden yola çıkan çalışmacılar krizin olası sebeplerine ilişkin farklı savlar ortaya koymuşlardır. Temsili demokrasiye yönelen eleştirilerin ortak dayanağı, bu modelin yurttaşları temel demokratik süreçlerden dışlamasıdır. $\mathrm{Bu}$ sorun, bireylerin katılımcı eylemlerden uzaklaşmasında, liderlerin gösterisel ve medyatik eylemlerinin artmasında ve siyasete olan ilginin azalmasında kendini göstermektedir.

Habermas gürültü kopartan eseri, Kamusallığın Yapısal Dönüşümü'nde oluşan, yükselen ve dönüşen kamusal alanın yolculuğunu -en azından burjuva açısından deneyimlenen yolculuğunu- anlatır. Ona göre, üstün kılınması gereken kamusal yaşamın ölüm fermanını yazan en önemli etkenlerden biri, gösterisel aleniyettir. Söz konusu aleniyet tarzı, iktidarın halk karşısında çıplaklaştırılması değildir. Yani, iktidarın halk tarafindan denetlenmesi ya da iktidarın hesap verebilirliği değildir. Anlatılmak istenen, siyasetin içinin boşaltılması ve ticari bir nesneye dönüştürülmesi sürecidir. Ona göre son dönemde bir çeşit siyasal marketing oluşmuştur. Eski tarz propagandacılar ve körükleyiciler yerlerini, reklam eksperlerine bırakmışlardır. Seçim rejisörleri devrededir. Hazırladıkları kurgusal çalışmayla gerçek kamusallığın kayboluşunu sadece izlemekle ve idrak etmekle kalmazlar; bu durumu bizzat ilerletirler. Geçici olarak oluşturulan siyasal kamusallık, entegrasyon kültürünün şart koştuğu alanı yeniden üretir. Siyaset sahası, sosyopsikolojik açıdan tüketim sahasına entegre edilir (Habermas, 2014: 353). Esasen kamusal alan üzerine yazında anlaşılması ve sonuca bağlanması güç birtakım engeller vardır. "Toplumsal gerçekliği kavramak için, araştırmacılar tarafından verimli bir biçimde kullanılan kavram; bilimsel ve gündelik kullanımı bakımından yoğun ve çeşitli anlamlara gönderme yapmaktadır" (Hekimoğlu, 2018: 545). Lakin Habermas'ın "her şeyden önce toplumsal yaşamımız içinde kamuoyuna benzer bir şeyin oluşturulduğu alan" şeklinde kısa ama sıkıştırılmış bir bilgiyle anlatmaya çalıştığı kamusal alan, bu süreçten nasiplenerek yalnızca görünüşte kamusal olan bir kamusallığa evirilmiştir.

Kamusallığ 1 , vazgeçilemez bir kıymet olarak nitelendiren ve kamusal alanı tam olarak 'hayat dolu' bir yer şeklinde gören Sennett, kamusal alanın bir zamanlar ki aktif yapısını çoktan yitirdiğini düşünür. Ona göre bunun nedeni Habermas'ın dikkat çektiği nedenlerle benzerdir. Günümüzün politik ve ekonomik akımlarına radikal eleştiriler getiren Sennett, günümüz kamusal alanında yaşanan bunalımlarının en önemli nedeni olarak politik eylemlerimize dikkat çeker. Sanat ve politikanın arasında güçlü benzerlikler taşıdığını belirtir. Her ikisi de star sistemi ile çalışmaktadır. Sahneye çıkacak olan politik adaylar güç grupları tarafından özenle hazırlanır. Aday, kitleler tarafından çabucak kabul edilebilir ve pazarlanabilir bir biçimde tasarlanır. Yurttaş-tüketicilerin beğenisine sunulur. Bu siyaset edimi kamusallığın ölümünü ilan etmekte ve bize yeni ama kamusal olmayan bir kamusallığın haberini vermektedir. Bu durum bizim düşün ve davranış dünyamıza sirayet etmiştir. Siyaset yapma biçimimizi belirlemektedir. Öyle ki, sadece kendi kahvaltısını hazırladığı için bir başkanı ötekinden daha güvenilir buluyor olabilmemiz ya da işçilere ağır vergiler getirirse getirsin bir başkanın medyatik bir biçimde işçi sinıfindan bir aileyle yemek yemesinin bizi heyecanlandırması bundandır. (Sennett, 2013: 44). Artık "çoğu yurttaş devletle ilişkilerine kanıksayıcı bir ruh haliyle bakmaktadır, yabancılarla kurulan ilişkiler en iyimser anlamda yavan ve kötümser anlamda da sahtedir" (Sennett, 2013: 11). Topluluk halinde kalmayı ve aktif yurttaşlar olarak toplumsal bir kolektifte varlık kazanmayı öylesine unutmuşuzdur ki, artık toplumu sadece psişik bir algı sistemi ile kavramaya başlamışızdır.

Kamuoyu artık, siyasetçiler üstünde bir nebze baskı oluşturan ve iletişim profesyonellerinin güdümüyle biçimlenen 'yoklamaların' etüt yeridir. Siyaset kamuoyu yoklamalarına dikkat kesilmişken, yurttaşların kolektif varlığ 1 da bu araştırmacılara indirgenmektedir. "Kamuoyu yoklamalarıyla yurttaş-denekler bir toplumun aktif üyeleri olarak değil, atomize tüketiciler olarak sorgulanmakta, sadece kendilerine yöneltilen soruları yanıtlamakta ve verdikleri yanıtların içeriğine göre istatistiksel verilere indirgenmektedir" (Doğanay, 2003: 34). Bu da kitle toplumu pekiştirmektedir. Bugün kamusallıktan kaçmanın bir yolu olarak yığınla insan sessizce kitle halinde kalmayı tercih etmektedir. Baudrillard, Sessiz Yığınların Gölgesinde ya da 
Toplumsalın Sonu adlı yapıtında bu durumu duyurmaya çalışmaktadır.

Modern demokrasinin içinde bulunduğu bunalım, farklı boyutlarıyla değerlendirildiği şekliyle bir meşruiyet krizidir. Liberal temsili demokrasinin kalbinde yer alana, eşitlik ve özgürlük ve özellikle halk egemenliği pratikte güvenilirliğini çoktan yitirmiştir. "Temsil sistemlerinin kavram ve yöntemleriyle, söz ve edim ürettiğini sanarak eylemeyi reddeden kitle, artık sessiz çoğunluktur" (Baudrillard, 1991: 19). Temsili demokrasinin uygulanabilirliğinin bittiğini söyleyen bu değerlendirmeler yeni bir demokrasi kavrayışına ihtiyaç olduğunu haber vermektedir. Öyle ki, Van ili kent merkezinde 500 kişi üzerinde gerçekleştirilmiş bir araştırmada bu gerçeklik bulgulanmıştır. "Şehir halkı, (\%54,8'lik oran ile) siyasal temsilcilerinin varlığına rağmen, kendilerinin siyasal ve sosyal olarak temsil edilmedikleri kanısındadır" (Bal, Bakan ve Koç, 2014: 133-141). Bunun gibi pek çok deneyim demokrasi konusunda tekerleği yeniden keşfetmemiz gerektiğini salık vermektedir.

Wright'ın 'Demokrasiyi Yeniden İcat Etmek' te geliştirdiği akıllı devlet kavramsallaştırmasında yurttaşların çıkarlarına hizmet eden ve yurttaşların devletin karar ve uygulamaları üzerinde daha doğrudan kontrol imkânına sahip olduğu bir sistem önerisinde bulunulmaktadır. $\mathrm{Bu}$ sistemin temel unsurlarından biri çıkarların temsilinden çok, kişisel özerkliği ve çoksesliliği öne çıkaran bir 'güçle mücadeleler alanı' önermesidir. Güçle mücadeleler alanı, siyaset dışının siyasallaştırılmasında ve kişisel hayatın demokratikleştirilmesi sürecinde özgürlük temeline dayalı toplulukların fonksiyon kazandığı bir kamusal alanı öngörmektedir. Bahsi geçen kamusal alan, özellikle günlük yaşamı etkileyen kurumlarda bireylerin güçlendirilmeleriyle daha anlayışlı, daha akılcı, daha hoşgörülü ve diğerlerine karşı daha duyarlı bir kamu ruhuyla hareket edebilecekleri fikrine dayanmaktadır. Halkın kolektif eylemlerle kendi görüşlerini ifade ettiği, rakip görüşlerle karşılaştığı ve siyasetin gündemine oturabilecek konuları tayin edebildiği bu kamusal müzakere alanlarından sahici bir demokrasiye önderlik etmesi beklenmektedir (Doğanay, 2003: 38-39). Bu tarz yurttaş etkinlikleri karar alma gücüne daha fazla insanın erişebildiği ve sınırları sermaye güçleri tarafından belirlenmemiş olan toplumsal mücadele alanlarının varlığı için oldukça değerli olacaktır. Bireylerin basitçe sandığa gidip oy vermesiyle yetinen temsil sisteminin buhranı, ancak bu tarz özgürlükçü ve katılımcı kamusal müzakere alanlarının varlığıyla aşılabilecektir. Kaldı ki, siyasetin düzenli olarak yinelenen seçimlere indirgenmiş olması, iktidara bir meşruiyet kazandırır gibi olsa da söz konusu iktidarı asla rasyonelleştiremeyecektir.

Böylece içinde bulunduğumuz temsili demokrasinin en önemli krizi olan meşruiyet sorunu, normatif ve geçici usullerin dışında hakiki çözümlere kavuşma imkânı yakalayacaktır. İktidarın meşruluğu sadece oylama sistemi ve yasa yapma sistemi ile açıklanamaz. Aynı zamanda diyaloğa ve iletişime dayalı olması gerekir (Keyman, 2007: 66). $\mathrm{Bu}$ açıdan demokratikleşme Keyman'ın ifadeleriyle; "Modern bürokratik devletin yasal-rasyonel hareket tarzını iletişimsel ussallık temelinde katılımcı demokratik yönetime dönüştürme sürecini niteler" (Keyman, 2007: 68). Katılım, yeniden yorumlama, tartışma ve müzakere ağlarıyla demokratikleşmeye yeni bir soluk gelmiş olur.
Vergin, oydaşma gibi bir kavramı sosyoloji literatürüne soktukları için Comte ve Durkheim gibi düşünürlere bu yüzden şükranlarını sunar (Vergin, 2014: 46).İletişimsel yönetim, aktif yurttaşlık, kültürel çoğulculuk ve katılımcı demokrasi gibi fikirleri savunan düşünürlerden öğrendiğimiz; uzlaşmadan uzak hiçbir otoritenin başarılı sayılamayacağıdır. Birbiriyle rekabet eden, hatta çatışan her bireyin ve her fikrin hem birbirinden hem de her deneyden öğrenecekleri vardır. Toplumsal tecrübelerimiz bize bunu öğretmiştir. Birlikte eylemeye ya da rekabet etmeye, konuşmaya ve dinlemeye yer veren böyle karşılaşma mekânlarına ihtiyacımız vardır. Özellikle de Türkiye gibi diğer ülkelere göre geç kalkınma ve uluslaşma sürecine girmiş ve demokrasi pratiklerinde kimi çatışkılar yaşayan bir ülkenin böyle karşılaşma alanlarına ihtiyacı vardır. Türkiye toplumunun sosyal süreci bunu gerektirmekte ve istemektedir. Gerçek bir demokrasiden bahsedilebilmesi için diyaloglar zemininde vücut bulan bir demokrasi deneyiminden söz etmek gerekir. "Diyalojik demokrasinin sağlanmasında, toplumun farklı kesimlerinin söz sahibi olması, tarafların birbirleriyle karşılıklı güven ve saygı çerçevesinde müzakere etmeleri önemli bir husustur" (Akıncı ve Usta, 2012: 94). Kamusal müzakere çabaları, bu noktada dirimsel önemdedir. Kamusal müzakere deneyiminin irdelendiği bu çalışmada demokrasi konvansiyonuna yönelmemin bir nedeni de budur.

\subsection{Demokratik Müzakerenin İmkânı}

Türkiye toplumunda -özellikle son dönemde- demokratik meşruiyet tartışmaları kapsamında ortaya çıkan az sayıdaki çalışmada, modern demokrasinin yurttaşların ortak yaşamlarını ilgilendiren konular üzerinde söz sahibi olmasıyla ve kamusal müzakere mekanizmaları aracılığıyla çözümlenebileceği ortaya serilmektedir. Bu yaklaşım, demokrasi krizine ve krizin çözüm yollarına dair temsili demokrasi kavrayışının dışında önemli bir bakış açısıdır. Bunun yanı sıra hâlihazırdaki kamusal pratiklerin, bireylerin ortak yaşamlarıyla ilgili yurttaşlar arasındaki kamusal müzakereler üzerine kurulu bir demokrasi deneyimine ne ölçüde imkân verdiği hala merak konusudur.

Toplumsal güç asimetrilerinin üstesinden gelmek "konuşma" hakkı üzerinde yeterince düşünmekle mümkün gibidir. Çünkü insanın en önemli eylemlerinden biri de kaçınılmaz olarak konuşmadır. Şöyle ki, "Dünyadaki şeylerden ne denli etkilenirsek etkilenelim, bunlar bizi ne denli derinden kavrarsa kavrasın, ancak başka insanlarla onlar hakkında konuştuğumuz zaman bizim için insanilik kazanırlar" (Berktay, 2015: 708). Eylemi kutsamasıyla tanınan ve konuşma eylemine özel bir yer veren Arendt'e göre ise "sözün söz konusu olduğu her yerde meseleler tanımı gereği politiktir; çünkü insanı siyasi bir varlık yapan sözdür” (Arendt, 2011: 30). Kamusal konuşmanın işleyiş koşullarını konu edinmesi bu yüzden bu çalışmanın ana meselesidir.

Modern demokratik toplumlar bir taraftan da karmaşıktırlar. Ve bu karmaşık toplumlar birtakım kamusal yararları güvence altına almak zorundadır. 'İletişim' ve 'katılım' güvence altına alınması gereken başlıca unsurlardandır. Ekonomik olarak daha müreffeh, daha meşru ve daha 'bir arada' bir toplum böylelikle mümkündür. Belki Habermas'ın izleğini önemli kılan şey de budur. Toplumun devlete kanal açma isteği, üzerine titrenilmesi gereken bir 
durumdur. Toplum ve devlet ilişkisiyle ilgili kararları ve düzenlemeleri tayin eden ilkelerin, kamusal müzakere içinde tartışmaya sokulması ve sorgulanması son derece önemlidir. Çünkü ancak, kolektif karar alma süreçlerinden süzülüp gelmiş bir demokrasinin sahiciliğinden söz edilebilir. Sıkça değindiğimiz gibi, siyaset sadece yönetsel bir tavır değildir. Daha çok karşılaşmayla, müzakereyle, tanımayla içkin bir meseledir. Birbirlerinden farklı bireysel ve kolektif kimliklerin arasında dayanışma olasılığı taşıyan bir sorgulama ve tartışma aktivitesidir. Kolektif karar alma süreçlerini devreye sokan bir mekanizma olarak kamusal alanlar, bu yüzden demokrasi için eşsiz bir potansiyeldir.

Habermas'ın kamusal alan fikri, eleştirel teori için ve içinde taşıdığı özgürleştirici dinamikler için vazgeçilmezdir. Aynı zamanda bu model, politik katılımı önemsemiş olduğundan ve bunun için de konuşma (talk) eylemini vurguladığından sahici bir demokrasi uğraşısı için kapı aralamaktadır. "Her şey ancak kamunun ışığında açığa çıkar, herkesin gözüne orada görünür. Meseleler vatandaşlar arasındaki konuşmalarda dile gelir ve şekillenir; eşitler arasındaki çatışma da en iyi olan ortaya çıkar ve gerçek özüne bürünür" (Habermas, 2014: 60).

Buradan varmak istediğimiz sonuç; iletişim pratiklerinin ne denli önemli olduğudur. Arzu edilen durum, kamusal kararların alınmasına etkin biçimde katılan bir eylemlilik halidir. Ve en açık, en basit eylem ise konuşma eylemidir. Bu eylemler, konuşmayı olduğu kadar, başkalarını dinlemeyi de içeren, buyurganlık yerine karşılıklılığı esas alan, özgür bireylerin birbirlerinin düşüncelerini ve eylemlerini şekillendirerek iletişime geçmelerini sağlayan bir kamusal eylemlilik biçimi izah etmektedir (Doğanay, 2003: 46-47). İzleyen bölümde Türkiye'deki kamusal müzakere süreçleri incelenmiş ve bu deneyimin demokratik potansiyeli sorgulanmıştır.

\section{Yöntem}

Araştırma yönteminin ne olacağı, neye ne şekilde yaklaşılması gerektiğini bilmeyi gerektirmektedir. "Zira bilgisini edinmek istediğimiz gerçekliğin nasıl bir şey olduğunu bilmeliyiz ki, gerçekliğin bilgisine hangi tür bilgi ile ve nasıl ulaşacağımızı (metodolojiyi) bilebilelim" (Dikeçligil, 2006: 31). Ancak çok az araştırmacı bir yaklaşımı tüm yönleriyle benimser ve o yaklaşımın önerdiği metodolojinin tüm parçalarını benimser. Araştırmacılar tarafından çoğunlukla farklı yaklaşımlardan unsurlar kaynaştırılır. Bu yaklaşımlar ve metodoloji kavrayışları sosyal bilim araştırmasıyla ilgili farklı varsayımları temsil eder (Neuman, 2017: 119).

Kimi çalışmalar kapsayıcılık açısından nicel araştırma yöntemini kaçınılmaz kılsa da, her araştırma mutlak suretle nicel yöntemle hazırlanamaz. Nitel araştırma yöntemi özellikle sosyal bilimlerin disiplinleri için oldukça elverişlidir. Çünkü her insan kendine özgü bir yapıya sahiptir. Sürekli içinde bulunduğu sosyal ortamın etkisiyle değişmeye meyillidir. $\mathrm{Bu}$ nedenle, insan sınırlı kalıplar içinde değil, esnek bir anlayışla kavranmak durumundadır (Demir 2014: 287). İnsanların sahip olduğu bu karmaşıklık ve anlaşmazlık, sosyal bilimlerde nitel yöntemlerin oldukça tercih edilmesinin başlıca nedenidir. Nitel araştırmalar, bu gereğin bir sonucu olarak ortaya çıkmıştır.
Nicel araştırma kadar yapılaşmış olmasa da, nitel araştırma yönteminin hiçbir keyfi yolu yoktur (Kuş, 2012: 78). Entelektüel bir bilmece etrafinda yoğunlaşılır ve bu bilmeceye sosyal açıklama getirilir. Esnek olsa da sistematiktir, bağlamsaldır ve eleştirel bir titizlik içinde yürütülür. $\mathrm{Bu}$ çalışma, nitel araştırma yöntemi ile hazırlanmış bir söylem analizini içermektedir.

"Söylem analizi metedolojik ve kavramsal unsurlardan meydana gelen sosyal hayata dair bir perspektif olup, söylem üzerine düşünme ve söylemi datalaştırma yolu olarak karakterize edilir" (Çelik ve Ekşi, 2008: 104). Foucaultçu bir okumayla; bilgi/güç tarafindan belirlenen pozisyonları değerlendiren söylem analizi, aynı zamanda politik ilişkilere odaklanıp bu ilişkilerin belli söylem çevresinde nasıl kurgulandığını anlamaya çalışır. Üstelik hâlihazırdaki söylemlerin özelliklerini de açı̆̆a çıkarma niteliğine sahiptir. "Kim neden konuşuyor, nasıl konuşuyor? Kim susuyor? Kim nasıl yazıyor, nasıl okuyor? Gibi sorularla başlayan söylem analizi, varsayımlardan daha çok belirsizliklerden hareket eder" (Sözen, 2017: 82-90). Farklı sistemler, farklı söylemleri biçimlendirir. $\mathrm{Bu}$ nedenle bu araştırmada üzerinde çalışılan "Sigara ve Madde Bağımlılığı" çalıştayının derinine gidilerek yüzeyin altındakileri çıkarmak esas olmuştur. Çalıştayda üretilecek söylemi belirleyen tüm söz ve söz ötesi değişkenler değerlendirilmek istenmiştir.

\section{Bulgular ve Yorumlar}

Bu bölümde, Batman Üniversitesi'ndeki "Sigara ve Madde Bağımlılığı" çalıştayı; söylem analizinin imkânlarıyla değerlendirilmekte; programın zamanı, mekânın kullanımı, katılımcıların kimliği ve müzakerenin işleyişi gibi çeşitli değişkenler aracılığıyla ilgili bulgular ve yorumlar yer almaktadır.

\subsection{Toplantının Zamanı ve Süresi}

İnceleme kapsamında ele alınan Sigara ve Madde Bağımlılığı Çalıştayı 9 Şubat 2018 tarihinde gerçekleştirilmiştir. Toplantının zamanı noktasındaki tercihi daha dar bir katılımcı beklentisiyle açıklanabilir. Toplantının Cuma günü mesai saatleri içinde yapılması, şehir dışından gelen katılımcılar ve çalışan insanların sürece dâhil edilmesi olanağına engel olmuştur. Çalıştay tüm gün sürmüştür. Çalıştay programında oturumların başlangıç ve bitiş saatleri ayrıntılı şekilde belirlenmiş olmakla birlikte, konuşmalar sırasında zamanın kullanımı açısından görece esnek bir akış benimsenmiştir. Lakin bu durum, katılımcılarda, konuklarda ve izleyicilerde dinleme kalitesi bakımından sorunlar yaratmaktadır. Özellikle daha geç saatlerde söz alabilen kimi konuşmacıların ilk konuşmacılara nazaran görüşlerini dinletebilmek açısından dezavantaj yaşamalarına neden olabilmektedir. Bununla birlikte programın uzun süreli olması 'söz hakk1' üzerinde zaman baskısı tarafindan oluşabilecek kısıtlamaları önleme çabası olarak da değerlendirilebilir.

\subsection{Mekânın Kullanımı}

Mekânın özellikleri gibi sözlü olmayan ya da söz ötesi değişkenler, anlam üretimini ve söylemin oluşumunu etkileyen önemli unsurlardandır. Gerçekleşen kamusallık sürecinin 'sahici' bir tartışma boyutu taşıyan, üretilmiş, 
önceden tasarlanmıș ve tanımlanmış bir deneyimi öne çıkarması nedeniyle bu tarz kamusal konuşma ortamları görsel düzenlemeler ile birlikte değerlendirilmelidir. Çünkü programdaki anlamın üretiminde ve oluşumunda farklı düzenbirimler devrededir (Doğanay, 2003: 252). Kullanılan mekân, konuşmacının, sunucunun ya da izleyicinin salon içindeki yerleşimi ve dekor düzeni program içinde belli bir söylemin üretilmesinde etkili olmaktadır.

Sigara ve Madde Bağımlılığı Çalıştayı üniversite ve valiliğin işbirliği ile gerçekleşmiştir. Çalıştayın yerel yönetimin işbirliği ile vücut bulması programın birçok yerinde ve anında kendini göstermektedir. Programın Batman Üniversitesine ait bir salonda gerçekleşmiş olması çalıştayın kurumsal kimliğini öne çıkarmıştır. Program Batman Üniversitesinin kent merkezindeki kampüsünde yer alan kongre salonunda düzenlenmiş ve katılımcılar burada misafir edilmişlerdir. Toplantının üniversiteye ait bir salonda gerçekleşmesi hareketin bağımlılı̆̆ açısından önemli bir unsur olarak değerlendirilebilir. Ayrıca toplantı mekânı olarak seçilen üniversite salonu 'halka ait bir mekân' yerine bu tür mekânlarda bulunma deneyimi olmayan katılımcıların sürece dâhil olmasını olumsuz etkileyebilecek bir durumdur. Salonda yer alan görsel değişkenlerle bu kurumsal durum pekiştirilmiştir. Arkada bulunan Batman Üniversitesi'nin logosu ile sigara ve madde bağımlılığı hakkında hazırlanmış bir pankart ile Atatürk resmi ve Türk Bayrağı ile toplantının kurumsal yanı vurgulanmıştır.

Oturumlar amfi şeklindeki büyük toplantı/kongre salonunda gerçekleşmiştir. Salonun büyüklüğü, katılımcı sayısının fazlalığı ve toplantı salonundaki ses dağılımı durumu konuşmacıların mikrofon kullanımını zorunlu kılmıştır. $\mathrm{Bu}$ durum, mikrofon deneyimi olmayan konuşmacıların ya da izleyici katılımcıların konuşmalara dâhil olmasını olumsuz etkileyebilmektedir. Örneğin Darras, (Akt. Doğanay, 2003: 225) kamusal konuşma içinde söz almanın mikrofona ulaşmayı gerektiriyor olmasının, mikrofonun kendi başına bir biçimselliği, meşru sözün alanını temsil etmesi dolayısıyla söylenen sözü etkileyeceğini belirtmektedir (1999: 74).

Programı, sahici bir kamusal alan görüntüsüne yaklaştıran en önemli etkenlerden biri programın görsel düzenlemesidir. Kimi araştırmacılara (örneğin Charaudeau ve Ghiglione'ye) göre at nalı ya da yuvarlak biçimde düzenlenmiş oturma düzeni sahicilik ve ciddiyet etkisi yaratacaktır (1997: 51-52). Yurttaşların kamusal müzakereye serbestçe katılabildikleri bir alan olarak 'antik agora'yı yeniden canlandırma fikri böyle kamusal müzakerelerin gerçekleştirildiği salonlarda pekişmektedir. Çalıştayın gerçekleştiği salonun daire biçiminde olması ve 'agora' biçiminde olması, iktidar odağı oluşturmak yerine konuşmacıların, dinleyicilerin ve katılımcıların birbirleriyle 'eşdeğer' konumlarını vurgulayıc1, birbirlerini görmelerini kolaylaştıran yapısı nedeniyle demokratik süreçler açısından olumlu bir görünüm sergilemektedir.

\subsection{Katılımcıların Kimliği}

Basın mensuplarına açık olarak işleyen Sigara ve madde bağımlılığı çalıştayı; Batman Valisi, Batman Üniversitesi Rektörü, Batman Belediye Başkanı, Batman İl Sağlık Müdürü, üç akademisyen, iş ve meslek danışmanı uzmanı ve bir hekimin konuşmacı olarak katılımıyla gerçekleşmiştir.
Katılımcılar arasında üniversite öğrencilerinin, valilik mensuplarının ve halktan dinleyicilerin bulunduğu programda izleyici; soru soran, alkışlayan, bağıran, gülüşen, söze karışan varlığıyla demokratik müzakere ve tartışma zemininin önemli bir parçası olarak belirmektedir. Üniversite, valilik, il sağlık müdürlüğü temsilcilerinin programda yer alması kamu kurumları arasındaki iletişim zemininin ve karşılıklı bilgi alışverişinin sağlanması açısından önemlidir. Diğer yandan katılımcıların farklı toplumsal kimlikleri yeterince yansıtmaması farklı yaşam deneyimlerinin süreç dışında bırakılmasına neden olmuştur.

\subsection{Müzakerenin İşleyişi ve Öne Çıkan Söylem}

Bilindiği üzere söylem analizi konusunda en başarılı ve sistematik çalışmalardan biri Teun van Dijk'in söylem analizidir. van Dijk, söylem yapılarını etkileyen toplumsal yapıları ortaya çıkarmada başarılı olmuştur (Sözen, 2017: 90). van Dijk' göre de program yapımcıları, yazarlar ya da uzmanlar gibi kendi iktidar çevreleri dâhilindeki söylemler hakkında karar verebilme konusunda nispeten özgür olan 'simgesel seçkinler' söylemin sunum şeklini, başlıklarını ve tarzını tayin edebilmektedirler. 'Bu 'simgesel seçkinler' kamusal tartışmanın gündemini belirleyebilen, bir anlamda kamusal bilgiyi, ideolojiyi, tutumları, değerleri, inancı, ahlak1 ve ideolojiyi ürettiklerinden, sahip oldukları simgesel iktidar aynı zamanda ideolojik iktidara dönüşebilmektedir" (Çevrimiçi kaynak: Teun A. Van Dijk Eleştirel Söylem Çözümlemesi, www.thebrandage.com, Erişim Tarihi: 27.06.2018). Bu açıdan değerlendirildiğinde programda söz hakkının düzenlenmesi ve toplantı gündeminin takip edilmesiyle ilgilenen bir görevlinin ya da bir moderatörün bulunmaması "yöneticilik" ya da "uzmanlık" durumunun getirdiği egemenlik konumunun aşılamamasına neden olmuştur. Kendi görüşlerini dile getirmek için araya giremeyen ya da konuşmacıların sözüne müdahale edemeyen dinleyiciler söz hakkının tek bir kişinin kontrolüne girmesine mani olamamışlardır. $\mathrm{Bu}$, basına ve halka açık olan kamusal konuşma pratiklerinde yönetici kimliğiyle yapılan egemenlik konumunun bir uzantısı olarak değerlendirilebilir. $\mathrm{Bu}$ yanıyla halkın ve öğrencilerinde katılımcı olduğu çalıştay; halkın kendi görüşlerini ifade ettiği, farklı hatta tezat görüşlerle karşılaştığı ve kolektif eylemlerle kamusal konuları tayin edebildiği bir kamusal müzakere alanına dönüşememiştir.

Çalıştay -izleyici ve/ya konuşmacı konukların tam olarak geldiklerine emin olan- protokol üyelerinin salona girmesiyle başlamıştır. Protokolün salona girmesiyle ayağa kalkan öğrenciler ya da sivil halktan dinleyici konuklar akla hemen elitizm teorisini getirmiştir. Vilfredo Pareto, Robert Michels ve Gaetano Mosca gibi klasik sosyologların çözümlemeleri bu noktada önemlidir.

Bilindiği gibi, Pareto ve Mosca gibi teorisyenlerin hareket noktası 'seçkinler' idi. Onlara (özellikle demokratik toplumlarda seçkinlerin kompozisyonunu daha kapsamlı inceleyen Mosca'ya) göre, gerek aydınlanmış, güçlü ve gelişmiş toplumlarda gerekse az gelişmiş toplumlarda iki sınıf bulunmaktaydı. Bunlar; her zaman sayısı daha az olan fakat erki elinde tutup erkin sağladığı üstünlükten yararlanan yönetici sınıf ile keyfi, meşru ya da zora dayalı biçimde denetlenen yönetilen sınıftı (Bottomore, 1996: 8-9). Protokol üyelerinin en son salona girmesi, protokol üyelerinin salona girmesiyle ayağa kalkan ve onların oturmasını bekleyen sivil 
halktan dinleyiciler ve sürekli olarak onların fotoğraflarını çekmeye çalışan basın mensuplarının kendi aralarındaki rahatsız edici rekabeti bir ölçüde elitizm teorisinin 21. Yüzyılda da kendine çalışma alanı bulabileceğini kanıtlamıştır. Vali, Rektör, Belediye Başkanı ve İl Sağlık Müdürü dolaylı ya da dolaysız olarak yönetimdeki olası etkileri yüzünden daha ayrıcalıklı olan üst katmanlar olarak karşımıza çıkmaktadır. Bu, bir yerde çalıştayın yerel yönetimle işbirliği içindeki görüntüsüdür. Bu görüntü ikinci konuşmacı olarak kürsü alan ve çalıştaya ev sahipliği yapan Rektör'ün ifadeleri ile perçinlenmiştir.

Rektör: “ $\mathrm{Bu}$, Valimizin de üzerinde çok durduğu bir konu. Bu yüzden biz birlikte bir çalışma düzenledik. Ben makine mühendisiyim. Az sonra branşlarından uzman hocalar konuşacak. Bu çalıştay vatanımıza millerimize hayırlı olsun, valimize şükranlarımı sunuyorum."

Programda il sağlık müdürünün ve rektörün ardından üçüncü olarak kürsü alan vali sahneye çıkar çıkmaz, tüm basın çalışanları etrafını çepeçevre sarmış ve ön sıralardaki konuklar, bir süre, sadece onun sesini işitebilmişlerdir. Vali teknik bir 'üstdil' seçmek yerine, programı müzakere yeri olarak görür biçimde bir 'muhabbet' dili kullanmıştır.

\section{Vali: "Önüme getirdikleri konuşma meninden konuşmayacağım." \\ Vali: "Aramızda matematiği kuvvetli olanlar söylesin bakalım, toplantı başlayalı beri 25 dakika geçmiş, bu verilere göre şimdiye kadar kaç kişi ölmüş?"}

Vali: "Bir de bana şeyi söyler misiniz arkadaşlar, ortalama bir paket ne kadar? Kaç ev yapıyor? Yahu matematikçi yok mu aranızda?"

Vali: "Evet kimler sigara içmiyor bir ellerinizi kaldırın bakalım (memnuniyet ifadesiyle) görüyor musunuz, Türkiye'nin geldiği noktayı..."

Vali: "Ben kahve kahve, sokak sokak geziyorum bıraktırmaya çalışıyorum."

Vali: "Bakın bir şey anlatayım, ne zaman oldu kaymakam bey biz ne zaman gitmiştik Sason'a?" "Birkaçı yan çizmiş."

Vali'nin resmi siyaset dilinden uzak, duygudaşlık ve iteleme gücü yüksek, somut insanlık halleriyle bezenmiş bu üslubu, programın samimi bir kamusal gövde oluşturulabileceğine yönelik potansiyeller taşımaktadır. Ancak belirtilmelidir ki, önceden hazırlanan kimi kurgusal unsurlar yüzünden program, bir vatandaş forumu olma özelliğinden uzaktadır. Örneğin Vali, sigarayı bıraktırdığı sivil halktan bir vatandaşı salona getirtmiş, konukların arasında oturan vatandaşı ayağa kaldırıp söz vererek bu süreci ve valiliğin bu süreçteki etkisini anlatmasını istemiştir. Yine konuşmasının aralarında (organ bağışı, okul öncesi, küfürsüz tezahürat gibi...) yaptığ1 çalışmaları anlatmış, sürekli kurumların çalışmalarına yer vermiş ve böylece yer yer "temsili söz"ün hâkim olduğu konuşmasında iktidarın sistemik yönlendirmesini yansıtmıştır. Böylece program, kurgusallık ile samimiliğin, sentetiklik ile gerçekliğin değiş tokuş edildiği bir yerde gibi durmaktadır. Toplumun ortak sorunlarıyla ilgili konularda, herkesin müzakereye katılabildiği her türlü ortam kıymetlidir. Eski Yunan Demokrasisindeki ‘agorayı' andıran böyle kolektivitelerde, egemenlik ilişkilerini işler hale getirecek işleyişlerin bulunduğu bu gibi deneyimler, bir demokrasi illüzyonunun yaratılmasına neden olabilmektedir.

Programda dikkate değer bir diğer durum da, protokol üyelerinin ve onca konuşmacının arasında sadece bir kadının kürsü almış olmasıdır. Batman Üniversitesi akademisyenlerinden olan kadın konuşmacı, çalıştayın üniversitede gerçekleşmesinde büyük payı ve emeği olan, programı koordine eden bir katılımcıdır. Çalıştayda yönetici, uzman ve erkek olmayan 'ötekilerin' sesinin cılız çıktığı bir söylem üretilmiştir. Örneğin, tüm protokol üyeleri erkektir. Bu, Türkiye'deki kamusal alan deneyimlerinin süzülüp geldiği patriarkal tarihsel süreçle ilgili gibidir. Eski Yunanlılar şehir ve ev hayatını ayırmışlar, politikanın ve şehrin alanı olan polis ile evin alanı olan oikos arasına bir sınır koymuşlardır. Modern insan kamusal alanı sorumluluklar alanı olarak; özel alanı ise daha doğal ve daha özgür bir alan olarak betimlemeye eğilimli. Oysa Yunanlılar için oikos, insanın kendini yeniden üretmesini sağlayan, içinde ekonomik faaliyetlerini de sürdürdüğü zorunlulukların alanıydı. Özgürlüğün dışına çıkmak için oikosun dışına yani polise çıkmak gerekiyordu (Gürbilek, 2016: 56). Oikos bu özgürlükten men edilmişlerin alanıydı. Kadınların, çocukların, kölelerin bölgesiydi. Politik karar alma süreci erkeklere tahsis edilirken, kamusal karar alma süreçlerinin çok uzağına düşen diğer yaşamsal etkinlikler kadınlara bırakılmıştı. Kamusal alan ortak yaşamla ilgili kararların alındığg ve tartışıldığ 1 , yasaların yapıldığg 1 ve uygulandığı, kültürün ve fikirlerin biçimlendirildiği bir alandır. Dolayısıyla çoğu kez bir erkek alanı olarak kurgulanan kamusal alanda, kadının görünürlüğü dirimsel öneme sahiptir. Bu deneyimlerin, yüzlerce bireyin gözünün önünde cereyan etmesi açısından, bu tarz 'forumların' cinsiyet açısından kapsayıcı olması fevkalade önemlidir.

'Söz hakkı' açısından değerlendirildiğinde; programın erkek, yönetici ve/ya uzman konuklar yararına düzenlendiği görülebilir. Örneğin çalıştaydaki en uzun konuşmayı yapan bir tıp profesörü, çarpıcı görseller sunarak ve taklitler yaparak sansasyonel kılmaya çalıştığı konuşmasında, cinsiyetçi bir söylem geliştirmiştir.

Tıp Doktoru Profesör : "Ben bayanlara sen kanser olacaksın dediğimde etkili olmuyor. Cildin kötü olur, pul pul olur, kırışır dediğimde işte o zaman telaşlanıyor."

Tüm kadınlar sanki sadece güzellik kaygısıyla karar veriyormuşçasına yapılan bu genellemede uzman konuşmacı, kadın dinleyicileri sigaradan caydırmak için yine güzellik üzerinden bir söylem geliştirmiştir. $\mathrm{Bu}$ sunuş, çoğunlukla özgünleştirme, somut olaylar veya eylemlerin genelleştirildiği ve olasılıkla soyutlandığı, dolayısıyla da iddianın bir yandan daha genişletildiği bir genelleştirme içermektedir. $\mathrm{Bu}$, van Dijk’e göre, söylemin bilişsel bir modelde temsil edildiği gibi daha somut bir örnekle; toplumsal davranışlar ve ideolojiler gibi daha genel düşünceler arasındaki bilişsel ilişkiyi işaret edebilme yöntemidir. Tekillik ve genelleştirme dinamikleri üretilecek söylem için politik olarak son derece önemlidir. Ayrıca olumsuz eylem ya da durumların genelleştirilmesi 
basmakalıplaştırma ve önyargının temelini oluşturmuştur (van Dijk, 2003: 91).

Yine erkek uzman konuşmacının bu sunuşu van Dijk'in ünlü zamir ikiliği (van Dijk, 2003: 17) BIZZ-ONLAR kutuplaşmasında kendini göstermiştir.

"Mantıklı bir birey sigara zaten içmez ama bayanlar hiç içmemeli."

"Bir bayanın ağzının kokması, saçının başının kokması ne iğrenç..."

"Bazen karı koca geliyor. Erkek içmiyor ama kadın içiyor. Bu var ya, bir evlilik için cinayet... Erkek içmezken kadının içmesi, kadının ağzının üstünün başının kokması çok pis. Pis bir şey bu!”

Kadınların marjinalleştirilmeleri sadece din, kültür ve aile yoluyla değil, bu kültürün taşıyıcısı olan dil yoluyla da sürmektedir. Örneğin bilim alanında çalışan bir erkeğin cinsiyet ayrımcılığı kodlarıyla döşeli bu ifadeleri kadına yönelik 'bakışın' ne olduğunu anlatan üzücü bir değerlendirmedir. Yine tıp doktoru olan bir diğer konuşmacı ise, benzer bir duruş sergilemiştir.

Tıp Doktoru Doçent: “Örneğin bir sarhoşa denk geldiniz, ana avrat sövüyor diyelim size... Bırakın sövsün, müdahale etmeyin. Erkeklik yapacağız diye, mertlik yapacağız diye..."

"Erkekler mertliğinizi böyle gösteremezsiniz. Kadınlar da öyle tabii..." Eliyle, (meme kanserine dikkat çekmek için tüm katılımcılara dağıtılmış olan) pembe kurdeleyi göstererek "Şeyi taktık, ayrımcılık yapmayalım."

Söylem "her birinin sonsuz şekilde birbirine bağlanabildiği kendi kategorileri ve unsurları olan birçok düzeyde yapıyı sunduğu için oldukça karmaşıktır" (van Dijk, 2003: 55). Açık bir şekilde ifade edildiği için çoğu kez kolayca fark edilebilen ideolojiler "aynı zamanda oldukça sezdirmeli, dolaylı, üstü kapalı bir biçimde, tonlama, duraksama veya bir zamir kullanmak gibi söylemin daha az belirgin yapılarında da meydana gelebilir" (van Dijk, 2003: 55). Ötekileştirmeler, konuşmaya eşlik eden birçok 'öte-sözel' örneğin, el kol hareketleri, yüz ifadesi, vücudun duruşu ve mesafesi, vb. gibi etkinliklerle de ifade bulabilir. Van Dijk'e göre bazen çok kurnazca hazırlanabilen bu yöntemlerle de bir insanı eşit, üstün veya aşağılık olarak görüp görmediğimizi gösterebiliriz (van Dijk, 2003: 43). Ya da bu örnekteki gibi sözde 'empati' içeren yadsıma cümlelerinde de vücut bulabilir.

Programda kimi söylemsel kapanma stratejileri göze çarpmaktadır. Programın incelenen bölümünde karşımıza çıkan dışlama stratejilerinden biri, belli olayların ve durumların tartışılmasının önlenmesine dönük engelleme stratejileridir. Buna konusal engelleme stratejisi de denir (Doğanay, 2003: 108). Çalıştay gündeminin ele alınış biçimi, büyük ölçüde konukların uzman kimlikleriyle biçimlenmiştir. İncelenen çalıştayın katılımcı kimlikleri, tartışmanın uzmanlar ağırlıklı bir yapıda şekillenmesinde etkili olmuştur. Bağımlılık, haliyle uzmanlık bilgisine mecbur bir sorun olarak tanımlanmıştır. Ancak sadece biyoloji temelinde inşa dilen söylemde dinsel, sosyolojik ve ekonomik yan etkiler yeterince tartışılamamıștır. Uzmanlık söyleminin tanıklık söylemine üstün kılındığı program, dışsal etkenlerin önemini kavramada yetersiz kalmıştır. Öğretim üyesi konuşmacılar oldukça didaktik bir söylem geliştirmişler, salondaki herkesin sağlıkçı olduğu önyargısından hareketle terminolojik bir anlatı seçmişlerdir.

\author{
"Hepimiz sağlıkçıyız, biliyorsunuzdur..." \\ "Hepimiz madem sağlıkçıyız biraz da sağlık \\ dilinden anlatalım."
}

"Bizler hekim olduğumuz için, bunlar zaten hepimizin bildiği şeyler."

Gerçekleşen tartışma süreci, uzman söylemini ve kimliğini öne çıkaran bir işleyiş ortaya koymaktadır. Program boyunca farklı biçimlerde 'yetkisizleştirme' stratejisi karşımıza çıkmıştır. Konuyla ilgili uzmanlık bilgisi ve deneyimi olanlar sunuşlarını arka arkaya yapmışlar ve tartışmalar sorucevapla sınırlandırılmıştır. Çalıştayda uzmanlık konumuna sahip katılımcıların oluşacak söylemi etkilemede öncelikli olduğu söylenebilir. Program 'ayrıcalıksız' katılımcıların söz hakkını kullanmaları noktasında adil bir işleyişe sahip değildir. Katılımcılar programa konuk olmayı kabul ederken aynı zamanda sunucu veya program yapımcısı tarafindan dayatılan 'idealleştirilmiş' söylemin direttiği kodları da kabul etmek durumunda kalabilmektedir. Bu yüzden üretilen söylemlere karşıt ya da rakip herhangi bir muhalif söz üretilememiştir. Program içinde uzmanlık kimliği olmayan yurttaşların, kadınların, öğrencilerin sözü işitilmemiş̧tir.

\section{Sonuç ve Öneriler}

Çalışmada ortak dünyaya ilgilerini yitirmiş ve bir araya gelme duygusu zedelenmiş bireylerin şekillendirdiği bir dünyada kamusal yaşamın üstünlüğünü savunmak kaçınılmaz sayılmış, söz konusu durumun ise ancak kamusal müzakere sorunu dikkate alındığında çözümlü olabileceği iddiası getirilmiştir. Bu araştırmada aktif bir aktör olarak yurttaşa yeniden eylemlilik kazandırmayı amaçlayan ve bu eylemlilik alanını 'kamusal konuşma süreçleri' içinde tanımlayan bir kamusallık zemini üzerinde durulmuştur. Çalışmada, biçimsel demokrasi modelinin dışladığı kesimler için, farklı toplumsal tecrübelerle biçimlenen alternatif kamusal alanların olup olmadığı üzerinden bir inceleme yapılmıştır. Çalıştayda üretilecek söylemin biçimlenmesi sırasındaki dışlama stratejilerinin neler olduğu görülmeye çalışılmıştır. Yeni kamusal alan tecrübelerini içeren bu tarz kolektivitelerin toplumsal eşitsizlikleri görünür k1lıp kılmadığı; enformasyon edinme, toplanma ve ifade etme gibi müzakereci demokrasinin kalbinde yatan iletişimsel eylemlerin buaralarda can bulup bulmadığı sorgulanmıştır.

İnceleme, kamusal müzakerenin ve kamusal konuşmanın farklı biçimlere varlık bulacak zeminlerinde genellenebilirlik kaygısı taşımadan, söylem analizinin el verdiği ölçüde gerçekleşen saptama ve gözlemler aracılığıyla gerçekleşmiştir. Bu yanıyla çalışma, bu alanda yapılacak daha geniş kapsamlı başka incelemeler için bir başlangıç oluşturma amacı gütmektedir.

Temsili demokrasinin bunalımlarını aşmak üzere insanların biraya geldiği, fikirlerini aktardı $\breve{g ̆}_{1}$, rakip fikirlerle karşılaştığı, ortak yaşamları ile ilgili müşterek sorunları hakkında birlikte eylediği bu tarz söylemsel etkileşim mekânları 'antik agora'yı yeniden canlandırabilmektedir. 
Monolog yerine, dinleyicilerin ve izleyicilerinde üretim sürecine dâhil olabildiği bir diyalog, daha önce başka yerlerde gerçekleşen kamusal tartışmaları şimdi bu tarz kamusal müzakere ortamlarında gerçekleştirmektedir. Aktif, katılımcı ve direngen bir dinleyici/izleyici modeli, kamusal alanın başlıca araçlarından birisi olarak yurttaş etkinliğini oluşturmaktadır. Ancak incelenen program bilgi/güç durumundan kaynaklı ayrımı ortadan kaldıramamış ve yapılan sohbetler sirasında izleyicilerin bulundukları mekânlar bir tür kasaba meclisine dönüşememiştir. Böylece 'yönetici' statüsünün tahtı sallanamamış, yapısal dişlama mekanizmaları aşılamamış ve farklı yaşam deneyimleri ön plana çıkamamıştır.

Eski Yunan Demokrasisinde halkın özgürce tartıştıkları ve karar aldıkları bir agorayı anımsatan program aslında 'kamusal alanın' bir simülakrasıdır. Çünkü izleyici konukları, uzman konuşmacı katılımcılardan ayıran araçlar 'oradadır.' Örneğin agorada sadece bir konuşmacı dışında hiç kadın yoktur. Ya da programda üretilen söyleme karşı direngen bir tavır geliştiren veya farklı görüşler dile getiren hiçbir 'katılımcı'nın sözü kamusal alana çıkamamıștır.

Fraser'in dikkatlere sunduğu gibi "bu durum bir kez daha göstermektedir ki, kamusal alana katılım yönündeki biçimsel kısıtlamaların kaldırılması, pratik olarak katılımın genişlemesini sağlamaya yardımcı olamamaktadır, tersine toplumun dezavantajlı kesimleri, katılım olanakları olsa bile, kamusal oylaşmanın dışında tutulmaktadır" (Fraser, 2015: 127). Kamusal sözün toplumsal yapıyı elbette etkilediği ancak kamusal alanın hâlihazırdaki toplumsal yapıdan nasiplendiği ortadadır. Kamusal alanın bir biçimde var olması, sistemik eşitsizliğin hüküm sürdüğü bir toplumsal düzende işe yaramayabilmektedir. Çünkü "Konuşma kendiliğinden demokrasiyi yaratmaz, demokrasi demokratik konuşmayı yaratır" (Schudson, 1997: 306).

\section{Kaynakça}

Akıncı, A. ve Usta, S. (2012). Müzakereci Demokrasilerde Sivil Toplum Kuruluslarının Rolü, Paradoks Ekonomi, Sosyoloji ve Politika Dergisi, Sayı: 2, s. 83-98.

Akınc1, A. (2011). Demokrasi ve Liberalizmin Zorunlu Birlikteliği, Paradoks Ekonomi, Sosyoloji ve Politika Dergisi, Say1: 1, s. 7-28.

Arendt, H. (2011). İnsanlık Durumu, (Çeviren: Bahadır Sina Şener). İstanbul: İletişim Yayınları.

Baudrillard, J. (2011). Simularklar ve Simülasyon, (Çeviren: Oğuz Adanır). Ankara: Doğu Batı Yayınları.

Bal, H.; Bakan, S.; Koç, Y. (2014). Sosyo-Politik Parametreler Açısından Van'daki Siyasal Temsil Anlayışı: İl Merkezi Üzerine Bir Araştırma, İletişim ve Diplomasi Dergisi, Sayı:3, s.128-152.

Berktay, F. (2015). Çoğulluk Yeryüzünün Yasasıdır, (Derleyen: Meral Özbek). Kamusal Alan, İstanbul: Hil Yayın. S. 707-712.

Bottomore, T. (1996). Seçkinler ve Toplum, (Çeviren: Erol Mutlu). İstanbul: Gündoğan Yayınları.

Çelik, H. \& Ekşi, H. (2008). Söylem Analizi, Eğitim Bilimleri Dergisi, Cilt: 27, Sayı: 27, s: 99-117.
Darras, E. (1994). Un Paysan a la Tele Nouvelles Missen e Scene du Politique, Reseaux: 63.

Demir, O. Ö. (2014). Sosyal Bilimlerde Araştırma Yöntemleri, (Edt. Kaan Böke), İstanbul: Alfa Yayınları.

Derdiman, R. C. (2006). Anayasa Hukukunun Genel Esasları ve Türk Anayasa Düzeni, Bursa: Alfa Aktüel Yayınları.

Dikeçligil, B. (2006). Sosyal Bilimler Epistemolojisinde Sorunların Kaynağı: Ontolojiyi Unutmak, (Hazırlayan: Ercan Şen). Felsefe ve Sosyal Bilimler: Muğla Üniversitesi Felsefe ve Sosyal Bilimler Sempozyumu Bildirileri, s. 31-51.

Doğanay, Ü. (2003). Demokratik Usuller Üzerine Yeniden Düşünmek, Ankara: İmge Kitabevi.

Ertan, B. (2004). Demokrasi ve yerel yönetimler. Review of Social, Economic\& Business Studies, Vol. 2, 204-215.

Fraser, N. (2015). Kamusal Alanı Yeniden Düşünmek: Gerçekte Varolan Demokrasinin Eleştirisine Bir Katk1, (Derleyen: Meral Özbek). Kamusal Alan, İstanbul: Hil Yayın, s. 103-133.

Giritli, İ. \& Sarmaşık J. (2001). Anayasa Hukuku, İstanbul: Beta Basım Yayım.

Görmez, K. (1997). Yerel demokrasi ve Türkiye. Ankara: Vadi Yayınları.

Gürbilek, N. (2016). Vitrinde Yaşamak 1980’lerin Kültürel İklimi, İstanbul: Metis Yayınları.

Habermas, J. (2014). Kamusallığın Yapısal Dönüşümü, (Çeviren: Tanıl Bora ve Mithat Sancar). İstanbul: İletişim Yayınları.

Hekimoğlu, G. (2018). Kamusal Alan: Toplumsal Katılımın Bir İmkânı, TİDSAD Türk \& İslam Dünyası Sosyal Araştırmalar Dergisi /The Journal of Turk \& Islam World Social Studies, Y11: 5, Say1: 19, Aralık, s. 543-555.

Hülür, H. \& Akça, G. (2007). İmparatorluktan Cumhuriyete Siyasal Bütünlük ve Ulusalcılık Söylemi, Sayı: 22, Konya: Türkiyat Araştırmalar Dergisi.

Kaypak, Ş. (2012). Yerel Yönetimlerde Katılımc1/Müzakereci Demokrasi Sürecinde Sivil Toplum Kuruluşlarının Önemi, Uluslararası Yönetim İktisat ve İşletme Dergisi, Cilt 8, Sayı 17, s.171-196.

Keyman, F. (2007). Kamusal Alan ve Cumhuriyetçi Liberalizm: Türkiye'de Demokrasi Sorunu, Ankara: Doğu Batı, Yıl:2, Sayı: 5, Kasım, s. 63-81.

Koç, Y. (2018) "Tahayyül Edilen Siyasal Bir Üst Kimlik: Osmanlıc1lı", Diyalektolog Ulusal Sosyal Bilimler Dergisi, Say1: 19, s.267-281.

Kuş, E. (2012). Nicel-Nitel Araştırma Teknikleri: Sosyal Bilimlerde Araştırma Teknikleri Nitel mi Nicel mi, Ankara: Anı Yayıncılık.

Neuman, W. L. (2017). Toplumsal Araştırma Yöntemleri, Nitel ve Nicel Yaklaşımlar 1. Cilt, (Çev. Sedef Özge). Ankara: Yayın Odasi.

Palabıyık A. ve Koç, Y. (2015). Millet-i Hakime Kavramı Üzerine Sosyo-Politik Bir Değerlendirme, Ulusal Sosyal Araştırmalar Dergisi, Sayı: 37, s.419-430. 
Schudson, M. (1997). Why Conversation is Not tje Soul of Democracy, US: Criticial Studies in Mass Communication, Volume: 14, p. 297-309.

Sennett, R. (2013). Kamusal İnsanın Çöküşü, (Çeviren: Serpil Durak ve Abdullah Yılmaz). İstanbul: Ayrıntı Yayınları.

Sözen, E. (2017). Söylem, Belirsizlik, Mübadele, Bilgi/Güç ve Refleksivite, İstanbul: Profil Kitap.

Vergin, N. (2014). Siyasetin Sosyolojisi: Kavramlar, Tanımlar, Yaklaşımlar, İstanbul: Doğan Kitap. van Dijk, T. (2003). Söylem ve İdeoloji Çok Alanlı Bir Yaklaşım, (Derleyen ve Çeviren: Barış Çoban ve Zeynep Özarslan). İstanbul: Su Yayınevi.

van Dijk, T. Eleştirel Söylem Çözümlemesi, (Erişim Tarihi: 27.06.2018, www.thebrandage.com.

Yatkın, A. (2006).Toplumsallaşma ve toplumsal demokratikleşme sürecinde sivil toplum kuruluşlarının yeri ve önemi. 9-10 Aralık 2006, Çanakkale: III. Uluslararası STK Kongresi Bildiler Kitabı. 